\title{
Humane endpoint in mice by Brazilian researchers in the vaccine sector
}

\author{
[Ponto final humanitário em camundongos aplicado por pesquisadores brasileiros \\ da área de vacinas] \\ F.R.C. Araujo ${ }^{1,2}$, R.L. Paixão ${ }^{3}$ \\ ${ }^{1}$ Aluna de pós-graduação - Universidade Federal Fluminense - Niterói, RJ \\ ${ }^{2}$ Fundação Oswaldo Cruz - Rio de Janeiro, RJ \\ ${ }^{3}$ Universidade Federal Fluminense - Niterói, RJ
}

F.R.C. Araujo1, 2 http://orcid.org/0000-0002-5452-1077 R.L. Paixão3 http://orcid.org/0000-0002-2895-9091

\begin{abstract}
The application of a humane endpoint (HE) for mice in vaccine trials and further challenging tasks with lethal samples is necessary to reduce or prevent pain and suffering in these animals, and is a refinement of the $3 \mathrm{R}$ policy enforced for animal testing in both national and international scenarios. In order to investigate the application of $\mathrm{HE}$ in Brazil, researchers from the vaccine sector have answered a questionnaire about their research profile, their usage of HE and their knowledge of its defining criteria, monitoring of animals, staff training, and euthanasia methods employed. The main results revealed that researchers failed to recognise the very concept of $\mathrm{HE}$ as well as when to apply it. In addition, the Institutional Animal Care and Use Committees (IACUCs) failed upon giving their approval to the trials. $\mathrm{HE}$ is an important refinament of animal testing policy, and these results highlight the need for a clear pre-established definition of when and how it should be implemented in order to ensure more effective application. Furthermore, it is important to clarify the ethics involved and the commitment of both the research teams and IACUCs to animal welfare.
\end{abstract}

Keywords: refinement, 3Rs, animal welfare, ethics, animal trials

\section{RESUMO}

A aplicação de um ponto final humanitário (PFH) em experimentos com vacinação e posterior desafio com amostras letais em camundongos é necessária para diminuir ou impedir a dor e o sofrimento desses animais, constituindo refinamento de acordo com a política dos 3Rs, vigente em âmbito nacional $e$ internacional, no cenário da experimentação animal. A fim de investigar a aplicação de PFH no Brasil, foi enviado um questionário para pesquisadores da área de vacinas, com perguntas sobre perfil do pesquisador, aplicação de PFH e critérios para sua definição, monitoramento dos animais, treinamento da equipe e métodos de eutanásia empregados. Os principais resultados revelaram que há falhas tanto em reconhecer o conceito quanto em aplicar o PFH, por parte dos pesquisadores, e que as CEUAs também falharam ao aprovar tais experimentos. Chama-se atenção para o fato de que o PFH é um importante refinamento e para a necessidade de definição prévia de PFH e sua aplicação, assim como para a importância do esclarecimento da questão ética envolvida e do necessário compromisso das equipes de pesquisa e das CEUAs com o bem-estar animal.

Palavras-chave: refinamento, 3Rs, bem-estar animal, ética, experimentação animal

\section{INTRODUCTION}

Trials in mice, which involve vaccination and further challenging tasks with lethal samples like toxins or pathogenic microorganisms, are commonplace in the Health sector. They subject

Recebido em 12 de janeiro de 2018

Aceito em 31 de agosto de 2018

E-mail: fernandarimolli@gmail.com the animals to great pain and suffering in the period between the challenging task and death (Casey et al., 2011; Stokes et al., 2011). In the stage following a challenging task, the animals can present a variety of symptoms, which include neurological symptoms, and, depending on the lethal agent in trial, can languish away for days before their death, greatly impacting the animals' 
welfare. The concept of the 3Rs - replace, reduce and refine-formulated by Russel and Burch (1959) is already a part of legislation worldwide and has been employed in the promotion of animal welfare in all sectors dealing with animal research. Brazilian law no. 11,794 (Brasil, 2008), which has been governing animal trials in the country since 2008, reads in Article 14, paragraph four: the number of animals in the performance of a project and the time allotted for each experiment shall be of the absolute minimum in order to produce the conclusive result and at best, spare the animals' suffering.

One of the most relevant actions for minimizing the suffering of animals subjected to lethal challenging tasks is the use of a humane endpoint (HE). It can be defined as "the earliest indicator in an animal experiment of (potential) pain and/or distress that, within its scientific context and moral acceptability, can be used to avoid or limit adverse effects by taking actions such as humane killing, terminating the study or alleviating their pain and distress" (Hendriksen et al., 2011).

In order to establish a $\mathrm{HE}$, it is necessary to consider a balance between meeting the scientific objective and sparing the animal from suffering (Ashall and Miller, 2014). Defining a HE that will also meet the scientific objective depends on the experience and commitment of the researcher in charge of the project. Quite frequently, scientific objectives only cover the scientific side and the animal's welfare is not taken into account. The criteria used in the application of a HE must be previously defined through pilot studies or through previous knowledge of the research team (Richmond, 1999; Morton, 2005). The monitoring of the animal and the knowledge of clinical signs of the disease are fundamental to decision-making. Monitoring protocols for the health and welfare of animals can be adapted for HE application (Franco et al., 2012b). However, it is essential that the research team be on the watch for possible unscheduled alterations in the program, which must be promptly addressed to ensure that the animals will not undergo further suffering that exceeds the amount previously planned and duly authorized by the IACUC (Ashall and Miller, 2014).

Although HE is prescribed by several institutions dealing with regulations and guidelines related to animal research, some studies on $\mathrm{HE}$ have highlighted the importance of its application in animals going through suffering and the general disregard on the part of the researchers (Hendriksen, 2011). Franco and Olsson (2012) pointed out that one of the problems related to the failure in the application of the $\mathrm{HE}$ is the absence of severity biomarkers for the diseases. They also mention a few studies aiming to come up with criteria for the use of HE.

Considering the relevance of the application of $\mathrm{HE}$ in animal trials, the present study was carried out so as to investigate whether Brazilian researchers are aware of the concept and whether they use it properly in their vaccine experiments with challenging tasks that utilize mice.

\section{MATERIAL AND METHODS}

The present project was sanctioned by the Ethics in Research Committee (CEP) of the Oswaldo Cruz Institute - FIOCRUZ as per Resolution no. 466/2012 from the National Health Council (Brasil, 2012), registration no. 773.762. Inclusion in the study had to meet one criterion: research professionals performing vaccination experiments followed by challenging tasks with lethal samples in mice.

From the current Brazilian directory (http://lattes.cnpq.br/web/dgp) (Diretório..., 2014), 223 research groups were identified that state the word vaccine and/or vaccines in their line of research. Those groups were contacted through available e-mail addresses. The message included an invitation to participate in the study along with the link for the online questionnaire. The same message was sent via e-mail to the national discussion network on the science of laboratory animals (Biotbras-L). Furthermore, researchers invited to the study were also requested to send out the link to other researchers in this area of study. Replies were received from September through October 2014.

The inquiry tool comprised of an electronic questionnaire elaborated with Google Forms®, running in the Google Drive ${ }^{\circledR}$ platform; there were 25 open, semi-open and closed questions. The questionnaire also included a presentation by the researcher in charge of the study along with the sentence "You were selected because your group has stated handling vaccines in your line 
of research", the Informed Consent Form, and a question about whether lethal challenging tasks were carried out (the very criterion for inclusion). Only upon responding to that question would the applicant be directed to the following questions. Next, an explanation of trials using mice read "HE is defined as the moment when the mice are subjected to euthanasia due to behavioral alterations or clinical signs suggesting they are about to suffer or are already suffering pointing to death", which was intended to avoid miss-interpretation. Following this definition, the questionnaire presented questions related to the respondent's profile, the interaction with their respective IACUC, the humane endpoint itself, questions about the defining criteria of $\mathrm{HE}$, animal monitoring, training of personnel, and euthanasia methods.

Data were prepared for analysis in the Google Drive ${ }^{\circledR}$ platform and analysed in the light of both quantitative and the qualitative approaches. Closed questions were transferred straight into a data sheet in order to calculate descriptive statistics, while the open questions were grouped into comprehension sheets and analysed according to the significant meaning of their answers, in line with the technique of content analysis (Bardin, 2009).

\section{RESULTS AND DISCUSSION}

In total, 29 researchers answered; they had all carried out trials related to vaccines with lethal challenging tasks in mice and they all agreed to join the study. Most of the participants have doctorate $(n=8,27.58 \%)$ or post doctorate $(n=$ $19,65.52 \%$ ) degrees, have been graduates for over 10 years $(n=25.86,20 \%)$ and have been working with mice trials over that time period $(n=21,72.42 \%)$, thus defining their profile as predominantly experienced in the use of animals. Participants also reported 30 different kinds of samples of infectious agents used in the challenging tasks.

All 29 participants (100\%) reported that they had submitted projects to IACUCs with information about the time of euthanasia. Only eight (27.59 $\%)$ reported that the IACUC questioned the application of HE. However, according to the participants, the questions from the part of the IACUCs were not about the criteria chosen for defining $\mathrm{HE}$ but rather about the method of euthanasia $(n=2)$ and the degree of suffering $(n=1)$. If all the participants informed their respective IACUCs about the moment euthanasia was performed and those committees did not question the criteria for the application of $\mathrm{HE}$, we should expect that the HE submitted to the committees were suitable and that all researchers involved would be following it. This does not correspond to the data collected by the present study. Therefore, by inference, the IACUCs failed to evaluate the rather aggressive protocols towards the animals, which could have easily been refined. In fact, Franco and Olsson (2013) have already signaled that the generalized belief in which ethical approval of protocols ensures good practice in research with animals is flawed, because a great number of sanctioned projects allow the intense suffering of animals, and that this suffering could have been avoided. Their work about the application of HE in studies with lethal models of Huntington's disease, in which the animals go through intense and painful suffering, showed no influence of approval or denial by either ethical or other regulatory bodies, according to the same authors (Franco and Olsson, 2013). This fact may indicate that IACUC members also fail to comprehend the concept of HE. According to Franco and Olsson (2013), it is likely that many of the committees believe that applying euthanasia to moribund animals is a humanitarian endpoint, when in fact, at that stage, the animal had already suffered intensely and the effectiveness of the euthanasia contribution to its welfare is relatively small. In addition, some committees might be acting much more bureaucratically rather than through a commitment to giving the animals an ethical treatment. Further still, even if the ethical review is rigorous, the researchers may well be disregarding recommendations, or may not be following procedures due to the scarcity of inspections (Franco and Olsson, 2013). In reality, Brazil lacks rigorous inspection into proceedings with animals in this research area.

The majority of researchers have answered positively as to the use of $\mathrm{HE}(\mathrm{n}=22,75.86 \%)$. This percentage is far higher than that found by Franco et al. (2012a). They reported that HE was applied in $26 \%$ lethal trials with tuberculosis published in 2009 and in just 19\% of trials with lethal models for Huntington's disease published between 1999 and 2009 (Franco and Olsson, 
2012). This difference might be due to the gap between the studies, as since the time of issue, $\mathrm{HE}$ has been growing in discussions within scientific forums. The increase in the use of $\mathrm{HE}$ within this period has also been evident in the work of Franco et al. (2012b). Among the articles on tuberculosis published between 1997 and 2003 that they examined, only $16 \%$ mentioned HE. This number grew to $28 \%$ between 2005 and 2009. However, note that the percentage of $75.86 \%$ relating to the number of researchers stating the use of $\mathrm{HE}$ in the present work does not reflect the percentage of those researchers who had indeed applied HE, which is $31.3 \%$ of researchers at best, but more like $13.79 \%$ in reality, as per the descriptions hereinafter upon evaluating their other questionnaire answers.

The participants were asked which behavioral changes and clinical signs the mice presented in the period following the challenging tasks. The question meant to elicit whether the researchers were able to identify and describe the criteria pointing to the severity of the disease, and identify the differences between those applying HE and not applying HE. Of the seven participants (24.13\%, group A) who did not use HE, six researchers answered that they observed that the mice displayed little change in behavior and clinical signs, as per Table 1. These findings show that follow-up in these cases is probably not intended for the health and welfare of the animals but for the scientific objective alone.

The answers collected from those making use of HE $(75.86 \%)$ were assembled in groups B through $\mathrm{E}$ in Table 1 according to the different stages at which $\mathrm{HE}$ is applied. However, note that three participants $(10.34 \%$, group B), according to their answers, do not apply HE; they are therefore unaware of the concept of HE and were unable to notice it even upon reading the description in the questionnaire. As to the other answers, seven participants $(24.13 \%$, group C) apply the endpoint when the animal is moribund or almost moribund, indicating that the animals are subjected to euthanasia when they become unresponsive to any stimulus, are cachectic, listless, prostrate and have breathing impairment; five (17.24\%, group D) apply the endpoint when the animals are going through intense suffering but are still not moribund; and four $(13.79 \%$, group E) apply HE in a somewhat humanitarian way. These findings show that indeed only $31.03 \%$ at best (groups D and E) apply HE, with this percentage more likely being just $13.79 \%$ (group E) since natural death as a consequence of the inoculated agent is not $\mathrm{HE}$, and neither can performing euthanasia to moribund or nearly moribund animals be considered as an appropriate application of HE. In general, the answers could have been more detailed (questions were open) and from the received answers it could be seen that the majority of participants do not apply $\mathrm{HE}$ accordingly; the animals are subjected to euthanasia after intense suffering and harm to their welfare. These findings also match those of Franco et al. (2012a, 2012b). They noticed that most mentions of $\mathrm{HE}$ in the articles from 2009 about tuberculosis reported the substitution of spontaneous death for the application of euthanasia in gravely cachectic moribund animals or animals about to die, which does not have a significantly positive impact on the mice's welfare. Furthermore, many lethal studies on tuberculosis allowed spontaneous death. Such a low percentage in terms of the application of $\mathrm{HE}$ also appeared in a study about articles published on lethal models for Huntington's disease; only $19 \%$ of the articles reported the use of HE, the majority of which stating that HE was applied primarily in moribund animals (Franco and Olsson, 2012). It is worth reiterating that these deaths should have been induced before they reach the utmost stages of suffering in order we considered a refinement of the trial (Toth, 2000).

Some of the provided pieces of information about the signs and alterations are incomplete, compromising our assessment of whether the signs were correctly observed, such as weight loss figures without a proper appraisal of rate and use of scale. There was also inadequate handling of several parameters, such as taking temperatures by touching which is an imprecise method. Some signs and alterations in certain studies may be relevant criteria for the worsening of health conditions leading up to death, but for these estimates to be informative, the research team must collect and analyse data using standardised, precise measurements (Scharmann, 1999; Morton, 2005). None of the researchers reported the use of score tables, a recommended tool for the monitoring of clinical signs in animals (Fentener et al., 2015). 
Table 1. Behavioral alterations and clinical signs reported by researchers both applying and not applying humane endpoint, and grouped as per application of $\mathrm{HE}$

\begin{tabular}{ll} 
Group & $\begin{array}{c}\text { Classification as per } \\
\text { application of HE. }\end{array}$ \\
\hline
\end{tabular}

Bristling, listlessness.

Lethargic, weight loss, skin lesions.

Goose bumps due to - probably - cold.

A Do not apply HE. Arched body, little movement.

It is necessary to follow protocol because we work with vaccination assays and challenging tasks, so every activity must check for the animals' resistance in order to demonstrate efficacy or not of vaccines.

Decreased appetite, hair loss.

I meet the term of the challenging tasks, which is relevant to my researches.

B Report use of HE but in truth the animals die as a consequence of the protocol.

In the case of Streptococcus, there is no Humane Endpoint once death is very quick (within 72 hours).

Parasitemia over $50 \%$.

The animals are subjected to euthanasia when they present locomotor problems, do not respond to manual stimuli, or when we note inability to feed or drink by themselves.

Thinning, bristling, cachexia.

Mainly prostration and bristling. Reduction in body temperature (on touch) has also been observed.

Apply HE when animals are

C almost moribund or

Piloerection, listlessness, anorexia, cyanotic mucous. moribund.

Breathing and feeding difficulties.

Weight, fur and prostration.

1. Weight loss $>=10 \% 2$. Clinical signs with score (score $>=3$ - euthanasia, score $=2-$ check every 2 hours); as per scale: Normal behavior $=0$; arched back plus slightly rugged skin $=1$; dropped eyes/harsh fur/subjugated but responsive $=2$; unsteady on feet/subjugated but unresponsive/nasal hemorrhage/blood in urine $=3$; prostration, eyes always closed $=4$.

Neuromotor signs like ataxia and lack of coordination.

Apply HE when animals are Ataxia, piloerection, behavioral unrest.

already subject to intense

Inability to feed or frequent seizures.

D suffering but not yet

Excessive weight loss. Fur loses shine and softness. Animal shows appetite loss, moribund. behavioral changes.

Behavioral changes, bristling, excess lethargy and breathing alterations.

Occurrence of an abscess on the spot where the tumor is growing and difficulties to move about (chiefly because the animals cannot feed properly).

Only one of the species of Leishmania we work with is lethal, and only for one of the lines of mice we utilize. In such animals, skin metastases at a distance appear where the inoculum was performed and infection reach internal organs and end up leading the animals to their death. Our trials are always restricted to the initial lesion and the animals are subjected to euthanasia before the development of skin

E Apply HE. or visceral metastatic lesions.

The two main points are paralysis, paresis. Despite the existence of other symptoms, these two are the ones that actually make it impossible for them to move around and reach food.

According to the response of the infectious agent in question, after the challenging task, it takes about 30 to 60 days for getting the expected immune response. The end of the trial usually happens within this period. If animals show any kind of alteration before the period above, euthanasia is applied beforehand.

${ }^{\mathrm{a}}$ Only 19 out of 22 participants answered this question by saying they apply humane endpoint. 
All 22 participants that reported the use of HE were asked about the frequency in which followup assessments of mice were held after a challenging task. As recommended (Fentener et al., 2015), eight researchers (33.36\%) reported that the animals were checked twice a day, which reduces the possibility of missing any changes besides the facility to monitor for sudden deterioration in the animal's health, which allows for the application of $\mathrm{HE}$ at the most suitable moment. Nine researchers $(40.91 \%)$ answered that the animals were checked once a day, which may be a frequency adequate for experiments with animals that do not show significant changes within a 24-hour period.

The other five $(22.72 \%)$ checked the mice between very long intervals - every two, three or seven days - which is not a recommended procedure for trials with lethal challenging tasks.

When participants were asked if follow-ups also occurred on weekends and holidays, 21 of them $(95.45 \%)$ answered positively and only one negatively. However, the answers appear to contradict the question about follow-up frequency when just 17 people, not 21 , informed us of follow-ups carried out for the animals once a day or more. Such conflict makes it clear that in some trials there is not a pre-established criterion for the frequency of follow-ups, thus rendering a humanitarian act such as $\mathrm{HE}$ ineffective when it is not applied at the right time.

Fifteen participants $(68.18 \%)$ informed us that they themselves participate in the follow-ups directly. This might be relevant data because, as most of them bear a doctoral degree and have more than 10 years experience with mice, it would be expected they are skilled in the monitoring of animals and, therefore, increase the prospect of the usage of $\mathrm{HE}$ as soon as the defining criteria are observed in the mice's activity. Seven participants $(31.82 \%)$ informed us that they did not take part in the follow-up. In such cases, it is utterly important that the researchers and all members of the staff be aware of established criteria for the $\mathrm{HE}$ and be capable of observing and recording them because, upon detection of these criteria during a follow-up procedure, HE can be promptly applied even in the absence of the head researcher.
Answers about the level of education of the people who carried out the monitoring showed six undergraduates, 10 holding bachelor's degrees, 13 holding master's, eight holding doctorate degrees and one holding a postdoctoral degree. As to the level of education of the 15 participants who directly participate in the follow-ups in mice, eight of them hold postdoctoral degrees, six are doctors and one is a specialist; most hold doctoral or post-doctoral degrees.

The participation of doctors and those with postdoctoral degrees in the follow-ups might signal that these professionals have, in theory, more experience than college students or graduate professionals. However, a follow-up performed by professionals holding educationally high degrees does not ensure that behavioral and clinical alterations are duly noticed and recorded with necessary accuracy. In order to properly monitor and apply HE, it is important that the person doing so is proficient in the identification of clinical and behavioral changes in the animal model. For that, they must know the biology and the normal behavior of the species subject to trial (Fentener et al., 2015; Hau, 1999).

According to the answers from the 22 participants who stated that they applied HE, 20 of them $(90.91 \%)$ answered that the people in charge of monitoring or performing follow-ups for the mice after the challenging tasks receive some training in order to enable that they effectively perform the activity.

It is of note that, despite the high percentage of answers stating the occurrence of training, the present work has previously discussed the failures and inadequacy of the clinical signs and behavioral alterations set by the participants as criteria for the use of HE. Therefore, the implementation of such training does not guarantee quality work when it comes to monitoring and HE. Furthermore, the training has to efficiently address essential specific information for the realization of the activities. Only four (18.18\%) out of 22 participants reported that their team training involves knowledge of biomarkers, and four others $(18.18 \%)$ mentioned that the only training undertaken involved attending a college module on Laboratory Animals, casting doubt on whether they had or had not been taught about 
the issue of HE nor about HE biomarkers for that specific trial. Six participants $(27.27 \%)$ mentioned that their training is held within lab premises, either by other lab mates or by themselves, i.e. the researchers in charge of the trials. Out of the remaining seven participants $(31.82 \%)$ were unable to give any details whatsoever about training except mentioning that such sessions occurred; one was a nonrespondent.

When questioned about the euthanasia methods employed, most $(n=17,58.62 \%)$ replied with the use of cervical dislocation, which is a restricted method due to its high demand for expertise. When duly applied though, it frees the mice from previous stress and suffering (Guidelines..., 2013). That percentage is higher than the one found in the work of Franco and Olsson (2012), where they report that in the articles published between 1999 and 2009 on Huntington's disease, $11 \%$ mentioned the use of cervical dislocation as their chosen method of euthanasia. One of the hypotheses explaining the numbers favoring this method in Brazil is that it uses no equipment or consumable supplies, thus having a low cost however, training is necessary.

The second most widely used method $(n=10$, $34.48 \%$ ) was $\mathrm{CO}_{2}$ without measurement of the concentration - this is not the proper way to use the gas. If lacking the right measurements, the gas, at wrong concentrations, may lead to the death of the animal by suffocation or hemorrhage, i.e. through suffering. The method without gas measurement is not accepted in Brazil, nor does the American Veterinary Medical Association (AVMA) (Guidelines..., 2013; Brasil, 2018; Guia..., 2013) recommend it.

The method of $\mathrm{CO}_{2}$ euthanasia with measured concentrations is accepted in Brazil with restrictions and should not be used whenever there are other methods available (Brasil, 2018; Guia..., 2013). However, five participants $(17.24 \%)$ stated that they used it. One of the participants stated using exsanguination by cardiac puncture without general anesthesia, an utterly unacceptable action due to the intense suffering caused to the animal. According to Franco et al. (2012b), exsanguination is often reported with missing data concerning an anesthetic in the articles on tuberculosis.
The other methods mentioned by the participants, namely, general anesthetics, barbiturates associated with other anesthetics, inhaling of anesthetics, and exsanguination by cardiac puncture after general anesthesia, are recommended by the National Council for Animal Experiment Control (Brasil, 2018), Federal Veterinary Medical Council (CFMV) and by AVMA (Guidelines..., 2012; Brasil, 2018; Guia..., 2013).

In respect to death confirmation, $89.66 \%$ of participants $(n=26)$ reported doing it regularly; however, this number does not corroborate the answers concerning the method of confirmation as only $62.07 \%(n=18)$ have stated they check for either cardiorespiratory arrest or absence of heartbeats as recommended (Guidelines..., 2013). However, only two participants (6.90\%) reported using a stethoscope in order to confirm death, which is important for checking for possible bradycardia or bradypnea in the mice and to avoid mistakenly considering them to be deceased. Only two researchers reported that death confirmation was given by a veterinary doctor, who is the only professional duly entitled to do so as per Brazilian law no. 5517/88 (Brasil, 1968).

\section{CONCLUSIONS}

This is the first study investigating the proceedings of the application of a humane endpoint among Brazilian researchers. Even bound by limitations such as a small sample size and restrictions as to comprehensiveness in the field of vaccine research, it was possible to verify that $\mathrm{HE}$ has not been usually used as a way of refinement, in other words HE is not in widespread use in terms of effectively preventing unnecessary animal suffering. In spite of amassing the highest percentage of positive answers for the application of HE compared to other studies, the present study in fact ended up revealing that the effective percentage the usage of HE is low, as with studies conducted abroad. It has highlighted that failure in the implementation of protocols related to HE occurs not only because they are not actively applied but also due to the researchers lack of knowledge of the concept, inaccurate follow-up for the animals, inadequate staff training, the usage of unacceptable methods of euthanasia and, last but not least, due to faults on the part of IACUCs. 
Our results suggest the need for some effort to incrementally improve the commitment of researchers and IACUCs to the sparing of animal suffering.

\section{REFERENCES}

ASHALL, V.; MILLAR, K. Endpoint matrix: a conceptual tool to promote consideration of the multiple dimensions of humane endpoints. Altex, v.31, p.209-213, 2014.

BARDIN, L. Análise de conteúdo. 5.ed. Lisboa, Portugal: [Edições], 2009. 281p. (Edições 70).

BRASIL. Lei Federal $\mathrm{n}^{\mathrm{o}} 11.794$ de 08 de outubro de 2008, estabelece procedimentos para o uso científico de animais. Brasília: Imprensa Nacional, 2008. Available in: <http://www.planalto.gov.br/ccivil_03/_ato20072010/2008/lei/111794.htm>. Accessed in: 8 Jan. 2018.

BRASIL. Lei Federal n ${ }^{\circ} 5.517$ de 23 de outubro de 1968, dispõe sobre o exercício da profissão de Médico Veterinário e cria os Conselhos Federal e Regionais de Medicina Veterinária. Brasília: Imprensa Nacional, 1968. Available in: <http://www.planalto.gov.br/ccivil_03/leis/L551 7.htm>. Accessed in: 8 Jan. 2018.

BRASIL. Ministério da Saúde. Conselho Nacional de Saúde. Resolução no 466, de 12 de dezembro de 2012, regulamenta diretrizes e normas para pesquisas envolvendo seres humanos Brasília: Ministério da Saúde, 2012. Available in: <http://conselho.saude.gov.br/resolucoes/2012/R eso466.pdf >. Accessed in: 8 Jan. 2018.

BRASIL. Ministério da Ciência, Tecnologia e Inovação. Conselho Nacional de Controle de Experimentação Animal. Resolução Normativa n³7. Anexo - Diretriz da Prática de Eutanásia. Brasília: Ministério da Ciência, Tecnologia e Inovação, 2018.

CASEY, W.; SCHMITT, M.; MCFARLAND, R. et al. Improving animal welfare and reducing animal use for human vaccine potency testing: state of the science and future directions. Procedia Vaccinol., v.5, p.33-46, 2011.
DIRETÓRIO dos grupos de pesquisa no Brasil Lattes. Available in: <http://lattes.cnpq.br/web/dgp >. Acessed in: 30 Aug. 2014.

FENTENER VAN VLISSINGEN, J.M.; BORRENS, M.; GIROD, A. et al. The Reporting of clinical signs in laboratory animals: felasa working group report. Lab. Anim., v.49, p.267283, 2015.

FRANCO, N.H.; CORREIA-NEVES, M.; OLSSON, I.A.S. Animal welfare in studies on murine tuberculosis: assessing progress over a 12-year period and the need for further improvement. PLoS One, v.7, e47723, 2012b.

FRANCO, N.H.; CORREIA-NEVES, M.; OLSSON, I.A.S. How "humane" is your endpoint? - Refining the science-driven approach for termination of animal studies of chronic infection. PLoS Pathog., v.8, e1002399, 2012a.

FRANCO, N.H.; OLSSON, I.A.S. "How sick must your mouse be?" - An analysis of the use of animal models in Huntington's disease research. Altern. Lab. Anim., v.40, p.271-283, 2012.

FRANCO, N.H.; OLSSON, I.A.S. Is the ethical appraisal of protocols enough to ensure best practice in animal research? Altern. Lab. Anim., v.41, p.5-7, 2013.

GUIA brasileiro de boas práticas para eutanásia em animais. Brasília: CFMV, 2013. 66p.

GUIDELINES for the euthanasia of animals. Schaumburg: AVMA, 2013. Available in: <https://www.avma.org/KB/Policies/Documents/ euthanasia.pdf $>$. Accessed in: 8 Jan. 2018.

HAU, J. Humane endpoints and the importance of training. In: INTERNATIONAL CONFERENCE, 1998, London. Proceedings..., London: Royal Society of Medicine Press, 1999. p.71-74.

HENDRIKSEN, C. Humane endpoints in vaccine potency testing. Procedia Vaccinol., v.5, p.221-226, 2011.

HENDRIKSEN, C.; MORTON, D.; CUSSLER, $\mathrm{K}$. Use of humane endpoints to minimize suffering. In: HOWARD, B., NEVALAINEN, T.; PERRETTA, G. (Eds.). The cost manual of laboratory animal care and use. Boca Raton: CRC Press, 2011. p.33-353. 
MORTON, D. Guia para el punto final humanitário em la experimentación animal para la investigación biomédica: aspectos éticos, legales y prácticos. Lab. Anim., v.8, p.5-12, 2005.

RICHMOND, J. Criteria for humane endpoints. In: INTERNATIONAL CONFERENCE, 1998, London. Proceedings... London: Royal Society of Medicine Press, 1999. p.26-32.

RUSSEL, W.M.S.; BURCH, R.L. The Principles of humane experimental technique. Potters Bar, UK: Universities Federation for Animal Welfare, 1959. (Special edition). Available in: <http://altweb.jhsph.edu/pubs/books/humane_ex p/het-toc>. Accessed in: 8 Jan. 2018.
SCHARMANN, W. Physiological and ethological aspects of the assessment of pain, distress and suffering. In: INTERNATIONAL CONFERENCE, 1998, London. Proceedings... London, UK: Royal Society of Medicine Press, 1999. p.33-39.

STOKES, W.S.; BROWN, K.; KULPA-EDDY, $\mathrm{J}$. et al. Improving animal welfare and reducing animal use for veterinary vaccine potency testing: state of the science and future directions. Procedia Vaccinol., v.5, p.84-105, 2011.

TOTH, L.A. Defining the moribund condition as an experimental endpoint for animal research. ILAR J., v.41, p.72-79, 2000. 